\title{
PENENTUAN VARIETAS BAWANG MERAH PADA LAHAN LITOSOL MENGGUNAKAN FUZZY MULTIPLE ATTRIBUTE DECISION MAKING (FMADM)
}

\author{
Nuraida Latif ${ }^{1}$, Ashari $^{2}$, Muh.Ramadhan ${ }^{3}$ \\ Teknik Komputer STMIK AKBA ${ }^{1,}$, Teknik Informatika STMIK AKBA ${ }^{2,3}$ \\ Email: nuraida@akba.ac.id ${ }^{1}$, ashari@akba.ac.id ${ }^{2}$
}

\begin{abstract}
ABSTRAK
Tanah litosol merupakan jenis tanah berbatu dengan lapisan tanah yang tidak begitu tebal dan miskin akan unsur hara. Sehingga diperlukan suatu pemecahan masalah untuk membantu para petani yang memiliki lahan berbatu litosol untuk memanfaatkan bibit bawang merah berkualitas untuk ditanam pada lahan berbatu (litosol). Penelitian ini bertujuan untuk merancang suatu system pengambil keputusan penentuan varietas bawang merah yang terbaik pada lahan berbatu (Litosol) dengan mengimplementasikan Model Fuzzy Multiple Attribute Decision Making (FMADM). Data-data diperoleh melalui Penelitian Lapangan, Penelitian Pustaka, dan Wawancara. Data-data tersebut dianalisis dengan menggunakan FMADM (Fuzzy Multiple Attribute Decision Making) metode Simple Additive Weighting (SAW). Hasil penelitian ini menunjukkan bahwa aplikasi sistem keputusan penentuan varietas bawang merah Pada Lahan Berbatu (Litosol) menggunakan fuzzy madm ini dapat memberikan informasi dengan cepat dan akurat untuk laporan varietas bawang merah terbaik pada lahan berbatu (litosol), yaitu : varietas Bima Brebes $(23,8)$, varietas Maja Cipanas $(22,55)$, varietas Kuning $(21,317)$, varietas Pikatan $(19,833)$, varietas Katumi $(19,083)$, varietas Sembrani $(18,533)$.
\end{abstract}

Kata Kunci : Fuzzy MADM, Varietas, Sistem Pendukung Keputusan, , SAW, Tanah Litosol.

\begin{abstract}
Litosol soil is a type of rocky soil with a less thick and poor soil layer that will not contain nutrients. To help farmers who have litosol rocky land to get quality red onion seeds to be planted on rocky land (litosol). This study discusses to discuss a decision-making system for the best shallot varieties on rocky land (Litosol) by implementing the Fuzzy Multiple Attribute Decision Making (FMADM) Model. Where data was obtained through Field Research, Library Research, and Interviews. These data were analyzed using FMADM (Fuzzy Multiple Attribute Decision Making) method of Simple Additive Weighting (SAW). The results of this study indicate that the application of the onion variety selection system on Rocky Land (Litosol) using fuzzy madm can provide information with help fast and accurate for reporting the best shallot varieties on rocky land (litosol), namely: Bima Brebes varieties (23.8), Maja Cipanas varieties (22.55), Yellow varieties (21,317), Pikatan varieties (19,833), Katumi varieties (19,083), Sembrani varieties $(18,533)$.
\end{abstract}

Keywords : Fuzzy MADM, varieties, Decision Support System, SAW, Litosol Land. 


\section{PENDAHULUAN}

Bawang merah (Allium ascalonicum L.) merupakan komoditas hortikultura berjenis umbi lapis yang memiliki banyak manfaat dan bernilai ekonomis tinggi serta mempunyai prospek pasar yang cukup baik. Bawang merah banyak digunakan sebagai bahan untuk bumbu berbagai macam masakan. Bawang merah juga memiliki manfaat lain yaitu sebagai obat tradisional karena mengandung banyak antiseptik dan senyawa aillin yang memiliki sifat anti mikroba termasuk bakteri sehingga berfungsi untuk menyembuhkan penyakit yang disebabkan oleh bakteri. (Nasrun M. : 2014)

Bagi Indonesia salah satu komoditi ekspor terbesar yang menghasilkan devisa bagi negara dalam bidang pertanian adalah bawang merah. Pusat produksi bawang merah tersebar diseluruh wilayah Indonesia, dengan luas daerah tanam bawang merah mencapai lebih dari 100 ribu hektar. Kementerian Pertanian Indonesia memprediksi bahwa produksi bawang merah nasional akan mencapai satu juta empat belas ribu ton atau bila dihitung per bulannya memproduksi sekitar seratus dua puluh ribu ton. Kebutuhan untuk dalam negeri sendiri untuk setiap bulannya, hanya memerlukan sembilan puluh ribu ton saja. Untuk mendorong akan meningkatnya produksi bawang merah, maka Pemerintah Indonesia akan mengembangkan Bawang Merah di kawasan tanaman sayuran APBN-P 2015. Pengembangan ini rencananya akan dilakukan di 27 dari 33 provinsi dimana meliputi $64 \mathrm{kota} / \mathrm{kabupaten}$ dengan perkiraan luas sekitar 1.732 hektar dan diharapkan mampu menghasilkan produksi $17.701,04$ ton per tahunnya.

Dari 27 kabupaten yang akan dikembangkan oleh Pemerintah, maka Kabupaten Enrekang merupakan salah satu kabupaten yang akan dikembangkan sebagai sentra produksi terbesar bawang merah untuk wilayah Indonesia bagian Timur. Dimana lahan atau tanah yang ada di Kabupaten Enrekang memiliki lahan berbatu (litosol). Para petani yang memiliki lahan berbatu (litosol) masih terkendala dalam memanfaatkan lahan tersebut untuk menambah produksi bawang di Kabupaten Enrekang. Dalam hal ini para petani masih memanfaatkan Bibit Bawang merah yang sama ditanam pada lahan yang lebih berpotensi dari pada lahan berbatu (litosol). Hal ini menyebabkan produksi bawang merah $\mathrm{f}$ lahan berbatu (litosol) tidak maksimal.

Berkaitan dengan hal tersebut di atas, maka diperlukan suatu pemecahan masalah untuk membatu para petani yang memiliki lahan berbatu (litosol) untuk memanfaatkan bibit varietas bawang merah berkualitas bantuan dari pemerintah daerah untuk ditanam pada lahan berbatu (litosol).

Salah satu cara yang dilakuan untuk menyelesaikan masalah tersebut yaitu penerapan teknologi informasi sistem pengambilan keputusan untuk menentukan atau memilih varietas bawang merah yang cocok untuk ditanam pada lahan bebatu (litosol) tersebut.

\section{LANDASAN TEORI}

\subsection{Fuzzy MADM (Multiple Attribute Decision Making)}

Fuzzy Multiple Atribut Decision Making (FMADM) adalah suatu metode yang digunakan untuk mencari alternatif optimal dari sejumlah alternatif dengan kriteria. Inti dari FMADM adalah menentukan nilai bobot untuk setiap atribut, kemudian dilanjutkan dengan proses perangkingan yang menyeleksi alternatif yang sudah diberikan (Kusumadewi, Harjoko, dan Wardoyo. 2006).

\section{Tahapan Fuzzy MADM :}

Proses dari FMADM ini dilakukan melalui 3 tahapan yaitu:

1. Pada tahapan penyusunan komponen situasi, akan dibentuk tabel taksiran 
yang berisi indentifikasi alternatif dan spesifikasi tujuan, kriteria dan atribut.

2. Pada tahapan analisis dilakukan melalui 2 langkah yaitu:

a) Mendatangkan taksiran dari besaran potensial, kemungkinan, dan ketidakpastian yang berhubungan dengan dampak-dampak yang mungkin pada setiap alternatif.

b) Melakukan pemilihan dari preferensi pengambilan keputusan untuk setiap nilai dan ketidakpedulian pada setiap resiko yang timbul.

3. Dan kemudian dilakukan tahap sintesis informasi.

Ada beberapa metode yang dapat digunakan untuk menyelesaikan masalah FMADM yaitu:

a. Simple Additive Weighting Method (SAW).

b. Weighted Product (WP).

c. Electre.

d. Topsis (Technique for Order Preference by Similarity to Ideal Solution).

e. Analytic Hierarchy Process (AHP).

\subsection{SAW (Simple Additive Weighting Method)}

Metode SAW sering dikenal dengan istilah metode penjumlahan terbobot. Konsep dasar metode SAW (Simple Additive Weighting) adalah mencari penjumlahan terbobot dari rating kinerja pada setiap alternatif pada semua atribut (Fishburn, 1967)

Metode SAW dapat membantu dalam pengambilan keputusan suatu kasus, akan tetapi perhitungan dengan menggunakan metode SAW ini hanya yang menghasilkan nilai terbesar yang akan terpilih sebagai alternatif yang terbaik. Perhitungan akan sesuai dengan metode ini apabila alternatif yang terpilih memenuhi kriteria yang telah ditentukan. Metode SAW ini lebih efisien karena waktu yang dibutuhkan dalam perhitungan lebih singkat.

Metode SAW membutuhkan proses normalisasi matriks keputusan $(\mathrm{X})$ ke suatu skala yang dapat diperbandingkan dengan semua rating alternatif yang ada. Metode ini merupakan metode yang paling terkenal dan paling banyak digunakan dalam menghadapi situasi Multiple Attribute Decision Making (MADM).

Algoritma Penyelesaian :

Dalam penelitian ini menggunakan Fuzzy MADM dengan metode SAW. Adapun langkah-langkahnya adalah:

1. Memberikan nilai setiap alternatif $\left(\mathrm{A}_{\mathrm{i}}\right)$ pada setiap kriteria $\left(\mathrm{C}_{\mathrm{j}}\right)$ yang sudah ditentukan, dimana nilai $\mathrm{i}=1,2, \ldots \mathrm{m}$ dan $\mathrm{j}=1,2, \ldots \mathrm{n}$.

2. Memberikan nilai bobot (W) yang juga didapatkan berdasarkan nilai crisp.

3. Melakukan normalisasi matriks dengan cara menghitung nilai rating kinerja ternormalisasi $\left(\mathrm{r}_{\mathrm{ij}}\right)$ dari alternatif $\mathrm{A}_{\mathrm{i}}$ pada atribut $\mathrm{C}_{\mathrm{j}}$ berdasarkan persamaan yang disesuaikan dengan jenis atribut (atribut keuntungan/benefit $=$ MAKSIMUM atau atribut biaya $/$ cost $=$ MINIMUM). Apabila berupa artibut keuntungan maka nilai crisp $\left(\mathrm{X}_{\mathrm{ij}}\right)$ dari setiap kolom atribut dibagi dengan nilai crisp MAX (MAX $\left.\mathrm{X}_{\mathrm{ij}}\right)$ dari tiap kolom, sedangkan untuk atribut biaya,

4. nilai crisp $\mathrm{MIN}\left(\mathrm{MIN}_{\mathrm{ij}}\right)$ dari tiap kolom atribut dibagi dengan nilai crisp $\left(\mathrm{X}_{\mathrm{ij}}\right)$ setiap kolom.

5. Melakukan proses perankingan untuk setiap alternatif $\left(\mathrm{V}_{\mathrm{i}}\right)$ dengan cara mengalikan bobot $\left(\mathrm{w}_{\mathrm{i}}\right)$ dengan nilai rating kinerja ternormalisasi $\left(\mathrm{r}_{\mathrm{ij}}\right)$.

Formula untuk melakukan normalisasi tersebut adalah : 


$$
r_{i j}= \begin{cases}\frac{X_{i j}}{\operatorname{Max} X_{i j}} & \text { Jika jadalah atribut keuntungan (benefit) } \\ \frac{\operatorname{Min}_{i} X_{i j}}{X_{i j}} & \text { Jika jadalah atribut biaya (cost) }\end{cases}
$$

dimana rij adalah rating kinerja ternormalisasi dari alternatif $A_{i}$ pada atribut $C_{j} ; i=1,2, \ldots, m$ dan $j=1,2, \ldots, n$. Nilai preferensi untuk setiap alternatif $\left(\mathrm{V}_{\mathrm{i}}\right)$ diberikan sebagai:

$$
\mathrm{V}_{\mathrm{i}}=\sum_{\mathrm{j}=1}^{\mathrm{n}} \mathrm{w}_{\mathrm{j}} \mathrm{r}_{\mathrm{ij}}
$$

Keterangan :

$\mathrm{V}_{\mathrm{i}}=$ rangking untuk setiap alternative

$\mathrm{w}_{\mathrm{j}}=$ nilai bobot dari setiap kriteria

$\mathrm{r}_{\mathrm{ij}}=$ nilai rating kinerja ternormalisasi

Nilai $\mathrm{V}_{\mathrm{i}}$ yang lebih besar mengindikasikan bahwa alternatif $\mathrm{A}_{\mathrm{i}}$ lebih terpilih.

\section{METODOLOGI}

\subsection{Teknik Pengumpulan Data}

Teknik pengumpulan data yang digunakan adalah sebagai berikut :

a. Studi Pustaka

Tahap pengumpulan data dengan cara studi pustaka dilakukan dengan cara mencari referensi - referensi yang sesuai dengan onjek yang akan diteliti. Dengan metode studi pustaka ini, dilakukan pengu mpulan data dan informasi dengan mencari, membaca, mencatat inti sari dan mempelajari buku-buku, referensi, jurnal yang relevan, situs-situs internet serta tinjauan pustaka yang berkenaan dengan topic yang akan dijadikan acuan pembahasan dalam penyusunan laporan ini.

b. Studi Lapangan

Penelitian lapangan dilakukan dengan mengumpulkan dan menelaah informasi mengenai potensi pengembangan bawang merah dengan metode observasi dan wawancara.

\subsection{Perancangan Diagram Model Data}

a. Use case Diagram

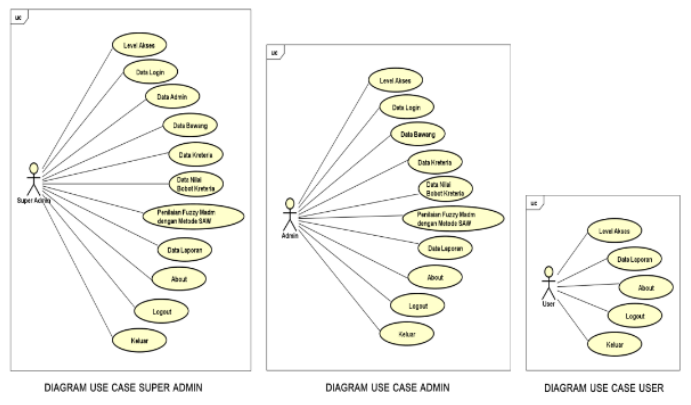

b. Activity Diagram

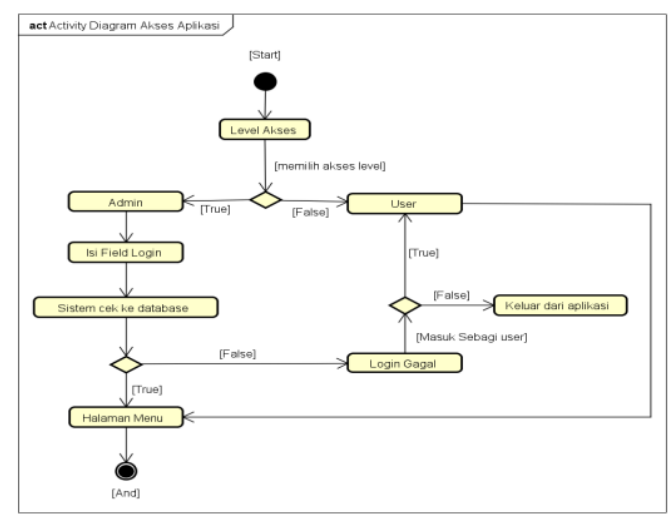

Kreteria - Kreteria yang di tentukan untuk pemilihan varietas bawang merah unggul pada lahan berbatu (litosol).

1) Ketinggian Tempat

2) Umur Panen (Hari Setelah Tanam)

3) Warna Umbi

4) Produksi Umbi Kering

5) Susut Bobot Umbi (Basah - Kering)

6) Ketahan Terhadap Penyakit

7) Adaptasi Pada Lahan Berbatu (Litosol) 
Sedangkan Alternatif yang digunakan yaitu jenis-jenis varietas bawang merah yang terdapat pada Tabel 1 .

Tabel 1. Jenis-jenis varietas bawang merah

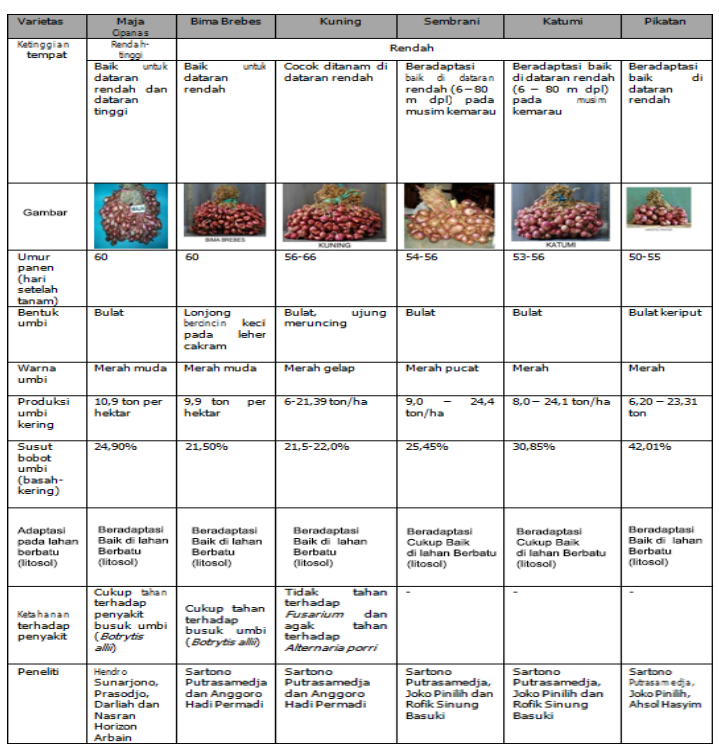

\section{HASIL DAN PEMBAHASAN}

Pengujian sistem dimaksudkan untuk menguji semua element perangkat lunak yang telah dibuat apakah sesuai dengan yang diharapkan. Pengujian yang dilakukan adalah pengujian blackbox. Pengujian black box adalah pengujian aspek sistem tanpa memperhatikan struktur logika internal perangkat lunak.

Pengambilan keputusan berdasarkan data yang ada untuk menentukan Kreteria yang dibutuhkan Varietas Bawang Merah terbaik pada lahan berbatu (Bobot W ) adalah :

Tabel 2 nilai bobot tiap kriteria

\begin{tabular}{|l|l|l|}
\hline Kreteria & \multicolumn{1}{|c|}{ Keterangan } & Bobot(W) \\
\hline K1 & Ketinggian Tempat & 3 \\
\hline K2 & Umur Panen (Pasca Tanam) & 5 \\
\hline K3 & Warna Umbi & 3 \\
\hline K4 & Produksi umbi Kering & 4 \\
\hline K5 & Susut bobot umbi (Basah - Kering) & 5 \\
\hline K6 & $\begin{array}{l}\text { Ketahanan Terhadap Penyakit } \\
\text { Bawang Merah }\end{array}$ & 4 \\
\hline K7 & $\begin{array}{l}\text { Adaptasi Terhadap Lahan Berbatu } \\
\text { (Litosol) }\end{array}$ & 4 \\
\hline
\end{tabular}

a. Ada 6 Alternatif varietas bawang merah yang akan dinilai berdasarkan data dari Jenis Jenis Varietas Bawang Merah yaitu :

A1 : Kuning

A2 : Bima Brebes

A3 : Maja Cipanas

A4 : Sembrani

A5 : Katumi

A6 : Pikatan

Table 3. Nilai Alternatif tiap kriteria

\begin{tabular}{|l|l|l|l|l|l|l|l|}
\hline \multirow{2}{*}{ Alternatif } & \multicolumn{7}{|c|}{ Kriteria } \\
\cline { 2 - 8 } & K1 & K2 & K3 & K4 & K5 & K6 & K7 \\
\hline Kuning & 3 & 3 & 4 & 2 & 4 & 2 & 4 \\
\hline $\begin{array}{l}\text { Bima } \\
\text { Brebes }\end{array}$ & 4 & 2 & 3 & 4 & 4 & 3 & 4 \\
\hline $\begin{array}{l}\text { Maja } \\
\text { Cipanas }\end{array}$ & 4 & 2 & 3 & 4 & 3 & 3 & 4 \\
\hline Sembrani & 3 & 3 & 2 & 4 & 3 & 1 & 3 \\
\hline Katumi & 3 & 4 & 5 & 3 & 2 & 1 & 3 \\
\hline Pikatan & 4 & 5 & 5 & 2 & 2 & 1 & 3 \\
\hline
\end{tabular}

Nilai yang di berikan terhadap Alternatif Varietas Bawang Merah yang akan ditanam pada lahan berbatu (litosol) di ambil berdasarkan dari Kriteria yang sudah di tetapkan. Berikut Alternatif Pemberian nilai Varietas Bawang Merah di ubah kedalam bentuk Matrix :

$$
X=\left[\begin{array}{lllllll}
3 & 3 & 4 & 2 & 4 & 2 & 4 \\
4 & 2 & 3 & 4 & 4 & 3 & 4 \\
4 & 2 & 3 & 4 & 3 & 3 & 4 \\
3 & 3 & 2 & 4 & 3 & 1 & 3 \\
3 & 4 & 5 & 3 & 2 & 1 & 3 \\
4 & 5 & 5 & 2 & 2 & 1 & 3
\end{array}\right]
$$

b. Melakukan Normalisasi Matrix

Dengan mengunakan Persamaan

$$
\begin{aligned}
\text { Rij } & =\text { Xij } / \text { Maxi }\{\text { Xij }\} \\
\text { R11 } & =4 / \operatorname{Max}\{4 ; 4 ; 3 ; 3 ; 3 ; 3\} \\
& =4 / 4 \\
& =1
\end{aligned}
$$

Sehingga didapatkan Normalisai Matrix sebagai Berikut : 


$$
X=\left[\begin{array}{ccccccc}
0.75 & 0.6 & 0.8 & 0.5 & 1 & 0.6666667 & 1 \\
1 & 0.4 & 0.6 & 1 & 1 & 1.0000000 & 1 \\
1 & 0.4 & 0.6 & 1 & 0.75 & 1.000000 & 1 \\
0.75 & 0.6 & 0.4 & 1 & 0.75 & 0.333333 & 0.75 \\
0.75 & 0.8 & 1 & 0.75 & 0.5 & 0.333333 & 0.75 \\
1 & 1 & 1 & 0.5 & 0.5 & 0.333333 & 0.75
\end{array}\right]
$$

c. Pengambilan Keputusan Memberikan bobot sesuai dengan Bobot preferensi Kreteria yang telah ditetapkan Sebagai kebutuhan untuk malakukan pemilihan varietas bawang merah unggul pada lahan berbatu (litosol) berdasarkan Kreteria Bawang Merah yang dibutuhkan sebagai berikut :

Bobot $(w)=\{3 ; 5 ; 3 ; 4 ; 5 ; 4 ; 4\}$

d. Berdasarkan data yang sudah ada maka selanjutnya akan dilakukan proses perengkingan dengan menggunakan persamaan sebagai berikut :

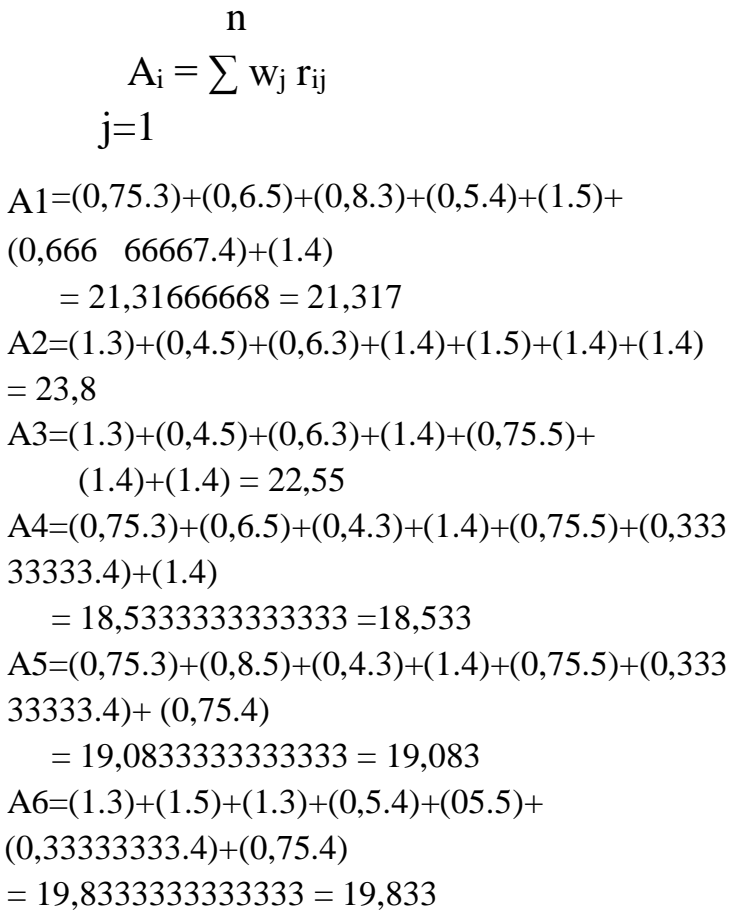

Sehingga di peroleh nilai total bobot kreteria kemudian disort descending berdasarkan hasil yang diperoleh Sebagai Berikut :
Tabel 3 : nilai total bobot

\begin{tabular}{|c|c|c|c|c|c|c|c|c|}
\hline \multirow[b]{2}{*}{ Alternatif } & \multicolumn{7}{|c|}{ Kriteria } & \multirow[b]{2}{*}{ Nilai } \\
\hline & $\begin{array}{l}K \\
1\end{array}$ & $\begin{array}{l}K \\
2\end{array}$ & $\begin{array}{l}K \\
3\end{array}$ & $\begin{array}{l}K \\
4\end{array}$ & $\begin{array}{l}K \\
5\end{array}$ & $\begin{array}{l}K \\
6\end{array}$ & $\begin{array}{l}\text { K } \\
7\end{array}$ & \\
\hline $\begin{array}{l}\text { Bima } \\
\text { Brebes }\end{array}$ & 4 & 2 & 3 & 4 & 4 & 3 & 4 & 23,8 \\
\hline $\begin{array}{l}\text { Maja } \\
\text { Cipanas }\end{array}$ & 4 & 2 & 3 & 4 & 3 & 3 & 4 & 22,55 \\
\hline Kuning & 3 & 3 & 4 & 2 & 4 & 2 & 4 & 21,317 \\
\hline Sembrani & 3 & 3 & 2 & 4 & 3 & 1 & 3 & 18,533 \\
\hline Katumi & 3 & 4 & 5 & 3 & 2 & 1 & 3 & 19,083 \\
\hline Pikatan & 4 & 5 & 5 & 2 & 2 & 1 & 3 & 19,833 \\
\hline
\end{tabular}

e. Keputusan yang didapatkan adalah Varietas Bawang Merah Bima Brebes yang paling unggul di lahan berbatu dengan nilai sebagai Varietas terbaik dengan nilai 23,8 .

\section{KESIMPULAN}

Berdasarkan penelitian yang dilakukan maka dapat diambil kesimpulan bahwa sistem pendukung keputusan ini dapat di implementasikan dalam hal membantu petani yang memiliki lahan berbatu (litosol) untuk menentukan varietas bawang merah yang akan di tanam pada lahan tersebut, dimana varietas yang terbaik adalah varietas Bima Brebes dengan nilai preferensi sebesar 23.8.

\section{DAFTAR PUSTAKA}

Ichwan. 2011.Pemprograman Basis Data Delphi 7 dan MySQL. Yogyakarta: Informatika.

Jogiyanto, H.M. 2012. Analisis dan Desain Sistem Informasi. Yogyakarta : Andi.

Kusrini. 2013. Konsep dan Aplikasi Pendukung Keputusan. Yogyakarta :Andi Offset.

Kusumadewi, Sri., Hartati, S., Harjoko, A., dan Wardoyo, R. revisi (2013). Fuzzy Multi-Attribute Decision Making (FUZZY MADM). Yogyakarta.Hlm 361:Penerbit Graha Ilmu. 
Marwah Sulehu. 2013. Pemrograman Visual III dengan Borland Delphi 7. Makassar: STMIK AKBA.

Nasrun M. 2014. Sekilas Tentang Bawang Merah.

http://bakorluh.ntbprov.go.id/berita -233-sekilas-tentang-bawangmerah.html : di akses tanggal 8 agustus 2016.

Suhari Ari. 2011. Komponen-komponen Sistem Informasi. http://arisuhari.blogspot.co.id/2011 /10/komponen-komponen-sisteminformasi.html : di akses tanggal 8 agustus 2016. 